\title{
Carotid artery inflow in operations to correct aortic diseases (ascending, arch and descending)
}

Circulação extracorpórea pela artéria carótida comum direita na correção de doenças da aorta ascendente, arco aórtico e aorta descendente

Januário M. SOUZA, Salomon O. ROJAS, Marcos F. BERLINCK, Ricardo MAZZIERI, Paulo A. F. OLIVEIRA, Jose Renato M. MARTINS, Dante F. SENRA, Rogério PETRASSI, Sérgio Almeida de OLIVEIRA

RBCCV 44205-628

Abstract

Objective: Femoral artery cannulation has been used as the preferred option in operations to correct ascending aorta and aortic arch aneurysms and dissections. The axillary artery is an alternative site for cannulation. We have used arterial inflow via the common carotid artery in nine patients.

Method: Nine patients were operated on with ages ranging from 46 to 80 years (mean $62.1 \pm 12.54$ ), six were male. Four patients had true aneurysms, three had aortic dissections and two a combination of dissections and true aneurysms. Five patients had undergone previous cardiovascular operations. Deep hypothermia with circulation arrest was used in two patients and in seven, antegrade cerebral perfusion was used.

Results: All nine patients awoke from the operation without cerebral damage. Two patients died, one on the $7 \mathrm{th}$ postoperative day due to respiratory failure and the other one on the third postoperative day due to a rupture of a thoracoabdominal aortic aneurysm.

Conclusion: The carotid artery can be a safe alternative of arterial inflow in operations to correct ascending aort and aortic arch diseases. This strategy allows antegrade cerebral perfusion during the operation even during arch resection and reconstruction.
Descriptors: Aortic aneurysm, surgery. Aneurysm, Dissecting, surgery. Extracorporeal circulation, methods. Carotid artery.

Resumo

Objetivo: A canulação da artéria femoral tem sido a via mais comum para o retorno arterial, nas operaçoes para correção de aneurismas ou dissecções da aorta ascendente ou arco aórtico. Mais recentemente, a artéria subclávia também tem sido usada. O objetivo deste trabalho é apresentar uma experiência inicial, com nove pacientes, em que se utilizou a artéria carótida comum direita para este retorno.

Método: Operaram-se nove pacientes com idade de 46 - 80 $\operatorname{anos}(62,1 \pm 12,54)$, seis eram do sexo masculino, quatro tinham aneurismas verdadeiros, três apresentavam dissecções e, em dois, havia combinação de dissecção com aneurisma verdadeiro. Eram cinco reoperações. Em quatro pacientes (reoperações) a circulação extracorpórea (CEC) foi estabelecida utilizando-se artéria carótida direita e a toracotomia foi feita quando a temperatura esofágica alcançou $20^{\circ} \mathrm{C}$, nesses casos a drenagem venosa foi realizada por uma das veias femorais. Nos demais pacientes, a CEC foi estabelecida entre a artéria carótida comum direita e o átrio direito. Em ambas situações a artéria carótida comum direita

Hospital Beneficência Portuguesa São Paulo, SP.

Cardiovascular Surgery Department (Team of Professor Sérgio A. Oliveira) Correspondence address: Januário Manoel de Souza. Rua Bahia, 753 $1^{\circ}$ andar. São Paulo, SP. Brazil, CEP 01244-001. Phone: (11) $3661-$ 9387/3661-9431 
foi incisada e um tubo de PTFE foi anastomosado à arteriotomia, sendo a linha arterial conectada a este tubo. A temperatura dos pacientes variou de 15 a $30^{\circ} \mathrm{C}$, dependendo da extensão da doença. $O$ tempo de CEC variou de 80 a 198 min. $(120,9 \pm 44,32)$. Em dois pacientes realizou-se parada circulatória, em sete pacientes utilizou-se hipofluxo (perfusão cerebral anterógrada)

Resultados: Sete pacientes tiveram boa evolução e dois faleceram, um por insuficiência respiratória no sétimo pósoperatório e outro por rotura de um aneurisma tóraco-

\section{INTRODUCTION}

For the correction of ascending aortic aneurysms and dissections, not associated with the aortic arch, the femora artery has been the most common via utilized for the arterial return of cardiopulmonary bypass (CPB), in spite of the already known complications [1,2]. But in the presence of peripheral artery disease (severe aorto-iliac obstructions, abdominal aorta and iliac artery aneurysms, extension of dissection to the femoral arteries) this via should not be used.

Retrograde perfusion by the femoral artery is also associated to bad cerebral perfusion in cases with aortic dissection, mainly in the acute phase [3]. Other arterial access vias have also been considered. NERI et al. [4] and other authors [5] utilized cannulation of the axillary artery in operations to correct type A aortic dissections giving good results. In this study the right common carotid artery was evaluated as an alternative via for arterial return of CPB in this type of operation.

\section{METHOD}

In the Cardiovascular Surgery Department of the Beneficência Portuguesa Hospital of São Paulo (Dr. Sergio Almeida de Oliveira's team) 860 operations for the correction of aortic aneurysms or dissections were performed, in the period from January 1979 to February 2002. From August to November 2001, nine patients were operated of which the right common carotid artery was utilized for the arterial return of CPB. The ages of these patients ranged from 46 to 80 years $(62.1 \pm 12.54)$. Six patients were male and four were operated on for the first time and five were reoperations. Four patients were suffering from true aneurysms, three had dissections and two combinations of dissections with true aneurysms. Tables 1, 2 and 3 show the clinical characteristics, anatomical diagnosis and the previous operations. abdominal no terceiro dia pós-operatório. Todos os nove pacientes acordaram sem qualquer seqüela neurológica.

Conclusões: Nesta técnica pode-se estabelecer a CEC antes da toracotomia, o que é importante nas reoperações, permitindo manter perfusão cerebral anterógrada com hipofluxo durante procedimento no arco aórtico.

Descritores: Aneurisma aórtico, cirurgia. Aneurisma dissecante, cirurgia. Circulação extracorpórea, métodos. Artéria carótida.

Table 1. Right Carotid Perfusion - Patients' Clinica Characteristics

\begin{tabular}{ll}
\hline Age (mean) years & 62.1 \\
Male & 6 \\
Arterial hypertension & 7 \\
Re-operation & 5 \\
Dissection & 3 \\
Aneurysm & 4 \\
Dissection + aneurysm & 2 \\
Urgency & 6 \\
Rupture & 1 \\
\hline
\end{tabular}

Table 2. Right Carotid Perfusion - Diagnosis (Aneurysm Position)

\begin{tabular}{ll} 
Asc ao & 1 \\
Asc ao + aortic arch + T-abd & 2 \\
Asc ao + aortic arch & 3 \\
Asc ao + aortic arch + Desc & 1 \\
Asc ao + COI & 1 \\
Asc ao + COI + MitralI & 1 \\
\hline
\end{tabular}

Ao - aorta; Asc - Ascending; T-abd - Thoraco-abdominal; Desc Descending; COI - Coronary insufficiency; MitralI - Mitral insufficiency 
Table 3. Right Carotid Perfusion - Previous Operations

\begin{tabular}{ll}
\hline Valved tube + coronary re-implantation & 2 \\
Aortic valve replacement + Pacemaker & 1 \\
Coronary artery bypass graft & 1 \\
Ascending aortic tube for dissection correction & 1 \\
\hline
\end{tabular}

\section{Indication and Surgical Technique}

The first patient of this series (Figure 1) had been submitted to coronary artery bypass surgery on 12/11/91, when three saphenous bypasses were implanted. In 1995, acute type A aortic dissection occurred but the patient was not operated on at that time as he was a Jehovah witness. In August 2001, the patient returned to our department with dissecting aneurysm (90 x $92 \mathrm{~mm}$ diameter) involving the ascending aorta, aortic arch, descending aorta and thoracicabdominal section. On this occasion he was 68 years old obese and with symptoms (pain and breathless) due to the extension of the aneurysm. Surgical treatment was indicated and accepted. Initially, the right common carotid artery was isolated, as was the left femoral vein, after heparinization (5 $\mathrm{mg} / \mathrm{kg}$ ), and an 8-mm PTFE tube was anastomosed on the carotid artery (Figure 2). The arterial line was connected to this tube and venous drainage was achieved by cannulation to the femoral vein.

$\mathrm{CPB}$ was established and hypothermia was initiated. When the esophageal temperature reached $20^{\circ} \mathrm{C}$, sternotomy was performed, at $15{ }^{\circ} \mathrm{C}$ the $\mathrm{CPB}$ was interrupted for 50 minutes, with intervals of arterial hypoflow with the brachiocephalic arterial branch clamped near to the inflow of the arterial line. The brachiocephalic vessels were isolated. A 22-mm Dacron tube was placed in the descending aorta using the elephant trunk technique [6]. The proximal portion of this tube was exteriorized and the brachiocephalic vessels were implanted in its orifice. The clamp was removed from the brachiocephalic artery branch, the arterial flow was normalized and the Dacron tube was clamped proximally to the brachiocephalic artery branch. Another 24-mm Dacron tube was anastomosed to the sinotibial junction of the aorta and the two tubes were anastomosed (end-to-end) (Figure 3). The three saphenous bridges were anastomosed to the Dacron tube. Re-warming of the patient started after the reimplantation of the brachiocephalic vessels. The patient was maintained sedated for 12 post-operative hours and awakened without any sequel. The post-operative study showed good results (Figure 4).

In another patient the circulation was arrested for a short time, but for the other seven patients cerebral anterograde

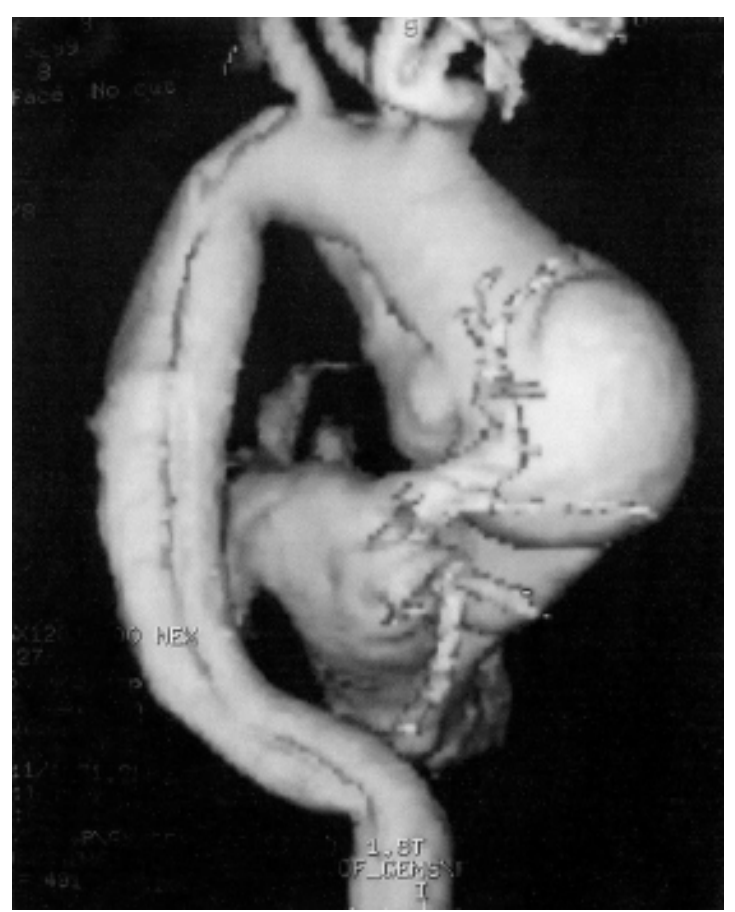

Fig. 1 - Magnetic angioresonance of the dissecting aneurysm of the ascending aorta, aortic arch and descending aorta.

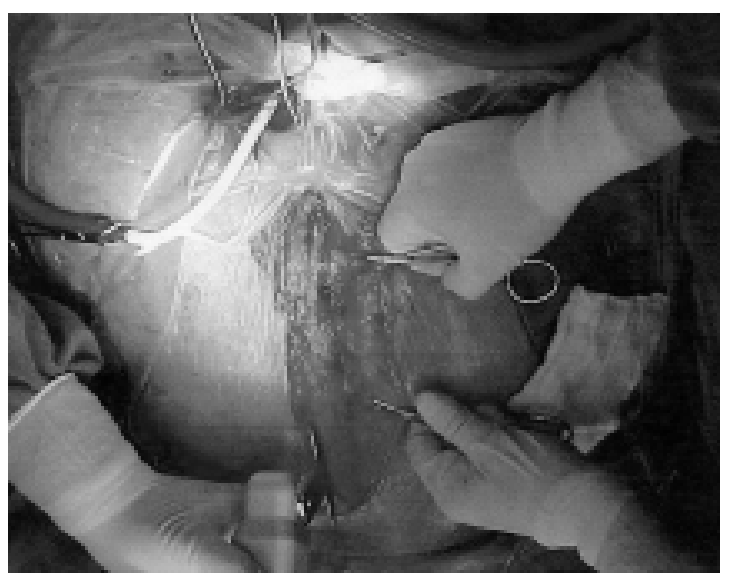

Fig. 2 - Perfusion by the right carotid artery through the PTFE tube connected to the arterial line of the cardiopulmonary bypass. Sternotomy when the temperature of the patient reaches $20^{\circ} \mathrm{C}$. 
perfusion by the carotid artery was maintained during all the surgical procedure. In two patients the carotid was approached by the sternotomy itself. The time of $\mathrm{CPB}$ ranged from 80 to 198 minutes (mean 120.8 minutes). The temperature of the patients varied from 15 to $30^{\circ} \mathrm{C}$. The operations performed are shown in Table 4.

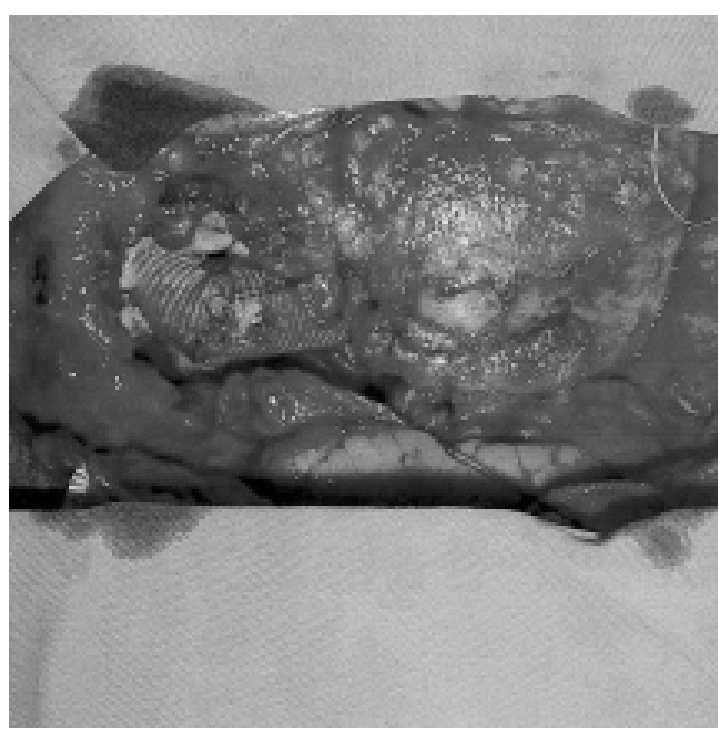

Fig. 3 - Final aspect of the surgery. Anastomosis between the two Dacron tubes and anastomosis between the saphenous vein bypass grafts and the tube.

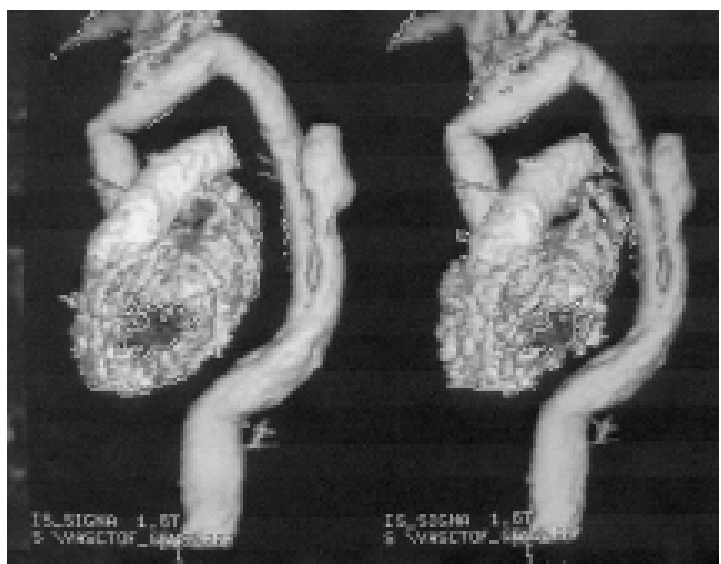

Fig. 4 - Post-operative study by magnetic angioresonance showing the tube substituting the ascending aorta and aortic arch and elephant trunk in the descending aorta.
Table 4. Right Carotid Perfusion - Operations

Asc Ao tube + aortic arch with brachiocephalic vein

+ trunk

Valved tube with aortic hemi-arch

Asc Ao tube + Aortic valve replacemen

Asc Ao tube + CABG

Asc Ao tube $+\mathrm{CABG}+$ replacement of mitral valve

Valved tube + aortic arch with brachiocephalic vein

+ trunk

Valved tube + aortic arch

\section{RESULTS}

All the nine patients awakened in the post-operative period without neurological sequels. Two patients died, one of respiratory failure on the seventh post-operative day. This patient was extubated on the second post-operative day but had presented with a bronchospasm on the following day and required re-intubation. This patient was obese and had a great abdominal eventration apart from being operated on at grade IV CCI for aortic bioprosthesis dysfunction and having a cardiac pacemaker. The other patient who died had a dysfunction of a previously implanted valved pericardial tube that was ruptured. This valved tube was replaced at the aortic arch, with re-implantation of the vessels by brachiocephalic and descending aorta (thoracic-abdominal) dissection. The patient was extubated on the second postoperative day without sequels. On the third post-operative day he died due to rupture of a thoracic-abdominal aneurysm.

The other patients were released from hospital in good clinical conditions. One 80-year-old patient remained in hospital for 30 days for nutritional support, as he was operated on with urgency (ascending aorta aneurysm associated to coronary insufficiency and unstable angina), in a bad general state.

\section{COMMENTS}

Cannulation of the femoral artery has been the most utilized via in operations for the correction of ascending aorta and aortic arch diseases, but it is contra-indicated or should not be used for patients who have abdominal aorta aneurysms or aorta-iliac obstructions because of the risk of embolization. Retrograde perfusion of the aorta from the 
femoral arteries implies a risk of bad perfusion (visceral, medullary and cerebral) by compression of the true lumen [4,5,7-9]. Circulatory arrest under deep hypothermia proposed by GRIEPP et al. [10] has been the most commonly used technique for the correction of aneurysms or dissections which compromise the aortic arch. Other techniques associated with retrograde cerebral perfusion [11] and hypothermia have been used.

Recently, it has been observed that anterograde cerebral perfusion is a better strategy to protect the cerebrum [1214]. KAZUI et al. [14] utilized anterograde cerebral perfusion by direct cannulation of the CBAT and left carotid artery after incision of the aneurysm. By utilizing perfusion by the carotid artery as we are proposing, it is possible to initiate $\mathrm{CPB}$ and hypothermia before opening the thorax. The thorax is opened at a low temperature, and it is possible to drain the patient and reduce the arterial flow, which diminishes the risk of bleeding due to injury of the aneurysm. During the procedure on the aortic arch, a cerebral anterograde flow of $300 \mathrm{ml}$-minute can be maintained without interruption.

\section{CONCLUSIONS}

The right common carotid artery is easy to access and can be evaluated in the pre-operative period by non-invasive methods such as Doppler and magnetic angio-resonance. This allows the CPB to be established and the hypothermia initiated before the thorax is opened. In re-operations, the thorax is only opened when the temperature of the patient is at $20^{\circ} \mathrm{C}$, which reduces the risk of lesion to the aneurysm. The technique allows the maintenance of anterograde cerebral perfusion during the entire operation, including procedures of the aortic arch thus avoiding air embolism and the entrance of fragments of the aorta, thrombi and calcium in the brachiocephalic vessels. Perfusion in the aorta is anterograde which avoids bad perfusion in the cases of dissection.

\section{BIBLIOGRAPHIC REFERENCES}

1. Price DL, Harris J. Cholesterol emboli in cerebral arteries as a complication of retrograde aortic perfusion during cardiac surgery. Neurology 1970; 20:1209-14.

2. Salerno TA, Lince DP, White DN, Lynn RB, Charrette EJ. Arch versus femoral artery perfusion during cardiopulmonary bypass. J Thorac Cardiovasc Surg 1978; 76: 681-4.
3. Borst HG In: Borst HG, Heinemann MK, Stone CD, editors. Surgical treatment of aortic dissection. New York: Churchill Livingstone; 1996. p. 255-68.

4. Neri E, Massetti M, Capannini G, Carone E, Tucci E, Diciolla $\mathrm{F}$ et al. Axillary artery cannulation in type A aortic dissection operations. J Thorac Cardiovasc Surg 1999; 118: 324-9.

5. Sabik JF, Lytte BW, McCarthy PM, Cosgrove DM. Axillary artery: an alternative site of arterial cannulation for patients with extensive aortic and peripheral vascular disease. J Thorac Cardiovasc Surg 1995; 109:886-91.

6. Borst HG, Frank G, Schaps D. Treatment of extensive aortic aneurysms by a new multiple stage approach. J Thorac Cardiovasc Surg 1988; 95:11-3.

7. Robicsek F, Guarino RL. Compression of the true lumen by retrograde perfusion during repair of aortic dissection. J Cardiovasc Surg 1985; 26:36-40.

8. Parr GV, Manley NJ, Williams DR, Montesano RM. Obstruction of the true lumen during retrograde perfusion of type I aortic dissection: a simplified solution. Ann Thorac Surg 1980;30:495-8.

9. Najafi H, Veeragandham R. Thoracic aortic operations management of maldistribution of arterial flow during cardiopulmonary bypass. Ann Thorac Surg 1997; 64:565-7.

10. Griepp RB, Stinson EB, Hollingsworth JF, Buehler D. Prosthetic replacement of the aortic arch. J Thorac Cardiovasc Surg 1975; 70:1051-63.

11. Ueda Y, Miki S, Kusuhara K, Okita Y, Tahata T, Yamanaka K. Surgical treatment of aneurysm or dissection involving ascending aorta and aortic arch, utilizing circulatory arrest and retrograde cerebral perfusion. J Cardiovasc Surg 1990; 31:553-8.

12. Midulla PS, Gaudsas A, Sadeghi AM, Mezrow CK, Yerlioglu $\mathrm{ME}$, Wang $\mathrm{W}$ et al. Comparison of retrograde cerebral perfusion to antegrade cerebral perfusion and hypothermic circulatory arrest in a chronic porcine model. J Card Surg 1994; 92:560-

13. Okita Y, Minatoya K, Tagusari O, Ando M, Nagatsuka K, Kitamura S. Prospective comparative study of brain protection in total aortic arch replacement: deep hypothermic circulatory arrest with retrograde cerebral perfusion or selective antegrade cerebral perfusion. Ann Thorac Surg 2001; 72:72-9.

14. Kazui T, Washiyama N, Muhammad BA, Terada H, Yamashita $\mathrm{K}$, Takinami et al. Total arch replacement using aortic arch branched grafts with the aid of antegrade selective cerebral perfusion. Ann Thorac Surg 2000; 70:3-9. 